\title{
Asthma and atopic disease in immigrants from Asia and the West Indies
}

\author{
JOHN MORRISON-SMITH* $\ddagger$ \\ M.D., F.R.C.P.(Ed.) \\ SUSAN M. COOPER $\dagger$
}

*Central Birmingham Chest Clinic, Dudley Road Hospital, Birmingham, and †Statistical Unit, West Midlan迈 Regional Health Authority

\section{Summary}

The clinical pattern of asthma and atopic disease was compared in 2331 children of European, Asian and West Indian parentage seen in Birmingham in the past 10 years. The main findings were that a higher proportion of children born in England of all races developed asthma within the first 4 years of life than children born abroad; the sex ratio of roughly 2 boys to every girl with asthma was similar in each race wherever born; the ratio of persistent to intermittent asthma was similar in each race wherever born; there was no difference in the proportion with eczema between the racial groups; hay fever and pollen allergy was less frequent in Asian and West Indian children even if born in England; hospital admission was more frequent in immigrant groups; positive skin reactions to grass pollen and domestic animals were more frequent in European children than in immigrants but positive reactions to house-dust mites were less frequent in European children.

It was considered that most differences could be explained on the basis of differences in environmental conditions and were unlikely to be of genetic origin.

\section{Introduction}

Over a period of 20 years the prevalence of asthma in children has been studied systematically. The authors have defined asthma in this context as recurrent wheezing and dyspnoea not known to be due to some other cause. The first study in 1956-57 (Morrison-Smith, 1961) included children of almost entirely European parentage but the later studies in 1968-69 (Morrison-Smith, Harding and Cumming, 1971) and in 1974-75 (Morrison-Smith, 1976) included many children of Asian and West Indian parentage, some born in England and some born in the countries of origin of their parents. These serial studies showed an increasing prevalence of childhood asthma over the period. The later studies also showed that children of immigrant families born in England had a similar prevalence of asthma to that in European children. However,

$\ddagger$ Address for reprints: Dr J. Mor rison-Smith, Clinical Investigation Unit, Dudley Road Hospital, Birmingham B18 7QH. children of immigrant families, particularly those from the West Indies, who had been born in the country of origin of their parents had a significant lower prevalence. This was probably most marked relation to families who had emigrated from poof rural areas of Jamaica.

Other studies in Africa and elsewhere have showi that children in the same racial group may have markedly lower prevalence of asthma in a poor rural area than in an urban area. Among the very primf tive people of the New Guinea Highlands, Anderson (1974) found asthma uncommon and virtual $x$ absent in childhood. Adult cases showed a clinical pattern similar to that of childhood asthma England. More recently, the authors have compar the clinical pattern of asthma and atopic disease some 2000 children of European, West Indian o Asian parentage seen at the Central Asthma Chinfe in Birmingham in the past 10 years.

\section{Results}

Between the years 1970 to 1980,2331 asthmat children were seen in the central Birmingham Chest Clinic. As seen in Table 1, a great many of these children although born in Europe were of Asian $\overrightarrow{9}$ West Indian origin. One thousand, six hundred and fourteen children first developed their asthma belo the age of 5 years. There was no significant difference in the sex ratio of $2: 1$ in favour of boys in al groups, although there was a non-significa tendency for there to be more Asian boys tha expected. There was a statistically significant ten ency for more European-born children $(71 \cdot 1 \%)$ to develop asthma before the age of 5 years compared with those born elsewhere $(40.2 \%)(P<0.001)$.

The clinical severity of asthma was considered very general terms and classified according to whether the wheeze was persistent or periodic. this basis there was no difference in severity in the 3 main ethnic groups. Despite this lack of difference when seen in the clinic there was a marked tendency for both Asian and black children to be admitted more often to hospital than the white children (whites $19.7 \%$, Asians $32.7 \%$, blacks $26.9 \%, P$ 娄 0.001 for Asians and $P<0.05$ for blacks). 
TABLE 1. Patients attending the asthma clinic $1970-80$

\begin{tabular}{lccccc}
\hline Place of birth & European & Asian & $\begin{array}{c}\text { Ethnic group } \\
\text { West Indian }\end{array}$ & Other & Total \\
\hline United Kingdom & 1541 & 228 & 343 & 86 & 2198 \\
Abroad & 13 & 97 & 14 & 9 & 95 \\
Total & 1554 & 325 & 357 & 2331 \\
\hline
\end{tabular}

The association of eczema with asthma was found in $707(34.9 \%)$ of children born in the United Kingdom and only $19(16.5 \%)$ of children born abroad. This relative rarity of eczema in those born abroad was statistically significant $\left(\chi^{2}=16.4, P<\right.$ 0.001 ). In particular, children of West Indian origin suffered more eczema $(39.6 \%)$ when compared with children of European (32.3\%) or Asian (33.9\%) origin, $(P<0.01)$. Symptoms of hay fever were present in $5.5 \%$ of Asian children, $14.7 \%$ of West Indian children and in $22.5 \%$ of white children; this trend was statistically significant $(P<0.001)$. However, no ethnic differences were seen in symptoms of chronic rhinitis.

A total of 146 children $(6.6 \%)$ had pidgeon chest deformity. This was present in $7 \cdot 1 \%$ of whites, $6.5 \%$ of Asians and in $3.2 \%$ of blacks. This tendency of blacks to have less chest deformity was statistically significant $(P<0 \cdot 01)$.

Skin-prick testing for allergies was conducted in 2185 children (Table 2). Positive reactions to housedust mites were common in all ethnic groups but were statistically more common in Asian $(P<0.001)$ and black children $(P<0.001)$. Skin reactions to pollen were generally more common in white children $(P<0.05)$, but independent of ethnic origin they were markedly less common in children born outside the United Kingdom $(P<0.005)$. Reactions to common foods such as egg, milk and fish were rather more common in West Indian children and less frequent in whites $(P<0 \cdot 001)$.
Allergic skin reactions to cat or dog dandruff were less frequent in children born abroad, and also in children of West Indian families $(P<0.002)$ and were more frequent in whites $(P<0.001)$.

\section{Discussion}

These data suggest that environmental rather than racial factors have a major influence on the prevalence of asthma and atopic disease. Children of various racial groups who develop asthma and are seen in England show some differences in pattern of symptoms but these differences are relatively minor and perhaps explainable on the basis of domestic conditions. In relation to the main characteristics of asthma and atopic disease, there is comparatively little difference particularly where children have been born in the same country

Previous studies have shown that the prevalence of asthma and atopic disease in children in the same racial group may be changed in one generation by immigration to a new country and a marked change of environment.

Children from abroad tended to develop asthma later and to have less eczema and hay fever. Racial differences were small and there was no apparent difference in the severity of asthma although admission to hospital was more frequent in the children of immigrant families. European children tended to have more pollen sensitivity and sensitivity to cats and dogs. The higher frequency of allergy to housedust mite in both ethnic minorities may be due to

TABLE 2. Number (and \%) positive and negative reactions to skin allergen testing (not all children underwent all tests)

\begin{tabular}{|c|c|c|c|c|c|c|}
\hline Allergen & & White & Asian & $\begin{array}{c}\text { Ethnic group } \\
\text { Black }\end{array}$ & Other & Total \\
\hline House-dust mite & $\begin{array}{l}\text { Positive } \\
\text { Negative }\end{array}$ & $\begin{array}{r}1025(71) \\
426(29)\end{array}$ & $\begin{array}{r}250(83) \\
51(17)\end{array}$ & $\begin{array}{r}294(86) \\
48(14)\end{array}$ & $\begin{array}{l}77(85) \\
14(15)\end{array}$ & $\begin{array}{r}1646(75) \\
539(25)\end{array}$ \\
\hline Pollen & $\begin{array}{l}\text { Positive } \\
\text { Negative }\end{array}$ & $\begin{array}{l}558(39) \\
863(61)\end{array}$ & $\begin{array}{r}84(28) \\
216(72)\end{array}$ & $\begin{array}{l}132(39) \\
209(61)\end{array}$ & $\begin{array}{l}28(31) \\
63(69)\end{array}$ & $\begin{array}{r}802(37) \\
1351(63)\end{array}$ \\
\hline Foods & $\begin{array}{l}\text { Positive } \\
\text { Negative }\end{array}$ & $\begin{array}{r}110(8) \\
1340(92)\end{array}$ & $\begin{array}{r}27(9) \\
273(91)\end{array}$ & $\begin{array}{r}47(14) \\
295(86)\end{array}$ & $\begin{array}{r}9(10) \\
82(90)\end{array}$ & $\begin{array}{r}193(9) \\
1990(91)\end{array}$ \\
\hline Animals & $\begin{array}{l}\text { Positive } \\
\text { Negative }\end{array}$ & $\begin{array}{r}450(31) \\
1000(69)\end{array}$ & $\begin{array}{r}78(26) \\
222(74)\end{array}$ & $\begin{array}{r}73(21) \\
268(79)\end{array}$ & $\begin{array}{l}19(21) \\
72(79)\end{array}$ & $\begin{array}{r}620(28) \\
1562(72)\end{array}$ \\
\hline
\end{tabular}


relatively more overcrowded living conditions. West Indian children had less chest deformity, more eczema and more frequent skin reactions to common foods despite their higher rate of breast feeding. Chronic rhinitis was equally common in all groups.

It was concluded that the pattern of symptoms showed comparatively little difference if children were born in the same country and racial differences probably played very little part in such differences as were seen.

\section{References}

ANDERSON, H.R. (1974) The epidemiological and allergec features of asthma in the New Guinea Highlands. Clinical Allergy, 4, 171.

MORRISON-SMITH, J. (1961) The prevalence and naturat history of asthma in schoolchildren. British Medic Journal, 1, 711.

MORRISON-SMITH, J. (1976) The prevalence of asthma and wheezing in children. British Journal of Diseases of the्f
Chest, 70, 73 .

Morrison-Smith, J., Harding, L.K. \& Cumming, G. (197 The changing prevalence of asthma in school children. Clinical Allergy, 1, 57. 